\title{
Three Most Troubling Factors in English Writing
}

\section{Kyoko Okamoto}

Meiji University

\section{Reference Data:}

Okamoto, K. (2020). Three most troubling factors in English writing. In P. Clements, A. Krause, \& R. Gentry (Eds.), Teacher efficacy, learner agency. Tokyo: JALT.

https://doi.org/10.37546/JALTPCP2019-57

The purpose of this study was to investigate the most troubling factors in English writing from students' viewpoints. A survey was conducted in 2018 and 2019 at a Japanese university. A total of 141 students responded to the questionnaire asking how they felt about 20 basic elements involved in academic writing such as brainstorming, outlining, organizing paragraphs, and using appropriate vocabulary. The participants rated their feelings about each item on a scale of 1 (not at all difficult) to 5 (very difficult). Two open-ended questions were also added to obtain information to supplement the objective data. The results showed that vocabulary, grammar, and paraphrasing were the most troubling factors for the students, which suggested that the students were more concerned about language-related problems than content-related problems. The possible reasons for the results are discussed, and implications for teaching academic writing in Japan are presented.

本研究の目的は、英語のライティングにおいて学生が最も難しいと感じる項目を調査することであった。2018年と2019年 の二度に渡り日本の大学において、アンケートを行い、141名の回答を得た。アンケケートでは、ブレインストーミング、アウトライ

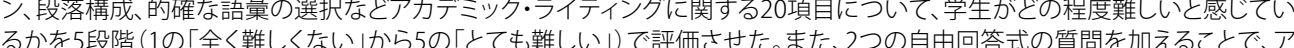
るかを5段階 (1の「全〈難しくない」か55の「とても難しい」)で評価させた。また２つの自由回答式の質問を加えることで、ア であっ結果の詳しい背景を探つた。しの調査の結果、学生が最難しいと感しているのは、語桑・文法・ハラフレーズの3項目 であったてれれよ、学生は書く内谷よも言語に関する閴題を気にかけているこかかかった。の調査結果の理由を考察 し、日本においてアカデミック・ライティングを教える際の留意点を提示した。
7 riting an English essay is not straightforward. It involves several skills, such as planning, organizing, explaining and developing ideas. Moreover, some skills need to be used at the same time. Bell and Burnaby (1984) said "Writing is an extremely complex cognitive activity in which the writer is required to demonstrate control of variables simultaneously" (as cited in Nunan, 1989, p. 36). In order to master such highly cognitive activities, students need to learn essential elements of writing an English essay, including a thesis statement, a topic sentence, and supporting sentences. Writing textbooks cover these components and they are taught in the classroom; however, many students have trouble mastering them. Then, among these essential components taught in the writing classroom, what is most difficult for students? Are there any elements that students should spend more time on than others? The purpose of this research was to find out the most troubling factors in English writing from students' viewpoints, rather than teachers'.

\section{Literature Review}

A great amount of research has been carried out to examine major problems of students' writing in the field of $\mathrm{L} 2$ learning, and what needs to be emphasized in the classroom has been countlessly discussed. One controversial issue is whether form-related or idearelated problems are of more concern to students. Although many conflicting results and claims have been presented in the literature, some quantitative research has reported the same or very similar findings on the issue.

Leki and Carson (1994) conducted a survey of former ESL students to examine their perceptions of writing needs in content courses, and 77 students responded to their survey. One question related to what the former ESL students would like to have learned or learned better in ESL writing. The most common item selected (30\%) was language skills; the item thinking skills was selected by only $4 \%$ of the participants. Moreover, individual items that were most frequently selected by the participants were vocabulary 
and grammar. The results of this survey clearly showed the students' concerns with form-related writing problems.

Evans and Green (2007) conducted large-scale research at an English-medium university in Hong Kong. They examined 4932 responses to their survey that asked the students, who were native speakers of Cantonese, to assess the level of difficulty about 15 items of academic writing. They found that the students' perceived major problems were language-related problems, such as vocabulary and grammar, rather than the content and structure. The following year, Lee and Tajino (2008) also conducted a survey at a highly competitive university in Japan to investigate the students' perceptions of difficulties by using 18 items of academic writing, including the 15 items from Evans and Green's survey. Ninety-five students responded to their survey, and the results showed that language-related items were perceived as more difficult than structure/content- related items by the participants. The results agreed with Evans and Green's findings.

Keong and Mussa (2015) conducted research on Islamic postgraduate students' perceptions of academic writing problems. In their study, 30 postgraduate students studying at a Malaysian university responded to the questionnaire on difficulties when writing academic essays in English. They found that the most difficult problem recognized by the students was a lack of vocabulary. Habibi and Husni (2017) also conducted a survey of 70 students at an Islamic university to examine students' perceptions of their writing problems and found that the most dominant problem claimed by the participants was word choice.

In Japan, the bulk of the research on students' writing problems has dealt with teachers' perceptions of their students' work; a lot less research has been done so far on students' perceptions of their writing problems, especially in a quantitative way. Such further research should reveal how students actually feel about English writing and what they really expect from their writing classes. In light of these reasons, this research was conducted to collect data of students' perceptions at a university in Japan. The research question for this study was "What are the most troubling factors in academic writing for EFL students studying at a university in Japan?"

\section{Methodology}

Participants

There were 52 ( 33 females, 19 males) participants in the first survey and 89 (66 females, 23 males) participants in the second survey. The second survey included 2 Korean and 3 Chinese students who could speak and write Japanese fluently. All the participants majored in liberal arts at a university in Tokyo, Japan. Participants were 1st-year students and required to take the Reading and Writing course twice a week in the first academic year. All the participants took the course on Mondays and Thursdays, when the author was on campus; as a result, the data were collected on the same days of the week. The students were required to submit three writing assignments in addition to book reports and vocabulary quizzes in a 15-week semester. Their English level was considered relatively high because the university admission required the proficiency equivalent to TEAP 309 (B2 level), TOEFL iBT 72, or Eiken Grade Pre 1. Their textbook for the course was North Star 4th edition 4, published by Pearson, which targeted from B1 to B2 levels in the CEFR. The textbook was selected by the course coordinator and reviewed at the end of each year by all the writing teachers to confirm if the textbook was appropriate for their students. The course was conducted in English, and students used only English during class.

\section{Procedure}

The research was initiated after institutional clearance had been obtained. The survey was conducted once at the end of fall semester in 2018, and once at the end of the spring semester in 2019. Both of the surveys were conducted after the students had already finished three required writing assignments. The first survey was conducted in three writing classes including the author's, and the second was conducted in five other writing classes excluding the author's. The author's class was excluded in the second survey because the author had been aware of the results of the first survey. In order to eliminate possible bias caused by the knowledge of previous research results, the author's writing class was not included in the second survey. The survey was distributed to participants in the classroom. It was explained that the survey had an educational purpose, responding to the survey was not obligatory, and the results would not impact their grades.

\section{Instrument}

As noted above, the instrument used for this research was a survey, which consisted of three parts. There were three questions about the participants under the heading of "About You" in order to find out the background of the participants. Such information might bring insights into the results of the survey. There were 20 questions about their perceptions of the writing components taught in the course. In the course, students were expected to master those 20 items listed in the survey. The participants were asked to rate their feelings about each item on a scale of 1 (not at all difficult) to 5 (very difficult). Two open-ended questions were added at the end of the survey sheet to obtain 
additional information about the participants' opinions on English writing. All the survey questions were written in English, and the participants' comments were also written in English (see Appendix A for the full survey sheet).

\section{Results and Discussion}

The First Survey (2018)

Table 1 shows the items with the three highest mean scores, that is, the most troubling factors in the first survey conducted in 2018 .

Table 1. Troubling Factors in English Writing, $2018(n=52)$

\begin{tabular}{clcc}
\hline No. & \multicolumn{1}{c}{ Factor } & Mean & SD \\
\hline 1 & Paraphrasing & 3.5192 & 1.0754 \\
2 & Grammar & 3.4207 & 0.9568 \\
3 & Vocabulary & 3.3846 & 0.9321 \\
\hline
\end{tabular}

Note. Data from a Likert-style survey: $1=$ not at all difficult, $5=$ very difficult. See Appendix B for the full results.

The most troubling factor in English writing was paraphrasing. The second was writing grammatically correct sentences. The third was using appropriate vocabulary. These three items consistently ranked high in both of the surveys conducted in 2018 and 2019.

The top factor paraphrasing involves skills to change words and sentence structures without altering the original meaning; therefore, it is reasonable to think that paraphrasing is closely related to vocabulary and grammar knowledge. It can be said that the results of this survey suggest that the major troubling factors recognized by the students were form-related problems rather than macro-level, idea-focused problems.

The Second Survey (2019)

Table 2 shows the items with three highest mean scores, that is, the most troubling factors in the second survey conducted in 2019.
Table 2. Troubling Factors in English Writing, $2019(n=89)$

\begin{tabular}{clcc}
\hline No. & Factor & Mean & SD \\
\hline 1 & Vocabulary & 3.7752 & 0.8495 \\
2 & Grammar & 3.7078 & 1.0358 \\
3 & Paraphrasing & 3.3932 & 1.0070
\end{tabular}

Note. Data from a Likert-style survey: 1 =not at all difficult, $5=$ very difficult. See Appendix B for the full results.

The top three items in the second survey conducted in 2019 were the same as those in the first survey, but in a different order. In this survey, the top troubling factor was vocabulary, the second was grammar, and the third was paraphrasing. The results showed students' concerns with language skills, again. The results of these two surveys agreed with those of several former studies of students' perceptions of writing problems (e.g., Bitchener \& Bastukme, 2006; Evens \& Green, 2007; Habibi, 2017; Keong \& Mussa, 2015; Lee \& Tajino, 2008; Leki \& Carson, 1994).

It should be noted that the factor vocabulary had the lowest standard deviation in both surveys, which means that the scores of each participant were very close to the means of both surveys. The participants seemed to agree on feeling a high level of difficulty toward the action of using appropriate vocabulary in their writing.

\section{Open-Ended Questions}

In the open-ended questions, the respondents were asked (a) What are the most important things they learned in the Reading and Writing course? and (b) What did you want to learn more in the course? About the first question, 121 comments were written These comments were organized into several categories that were generated from the collected data and are shown in Table 3. 
Table 3. The Most Important Things Students Reported Learning in the Course

\begin{tabular}{|c|c|}
\hline Category & Number of comments \\
\hline Organization & 38 \\
\hline Writing procedure & 17 \\
\hline Assertiveness & 9 \\
\hline Vocabulary & 9 \\
\hline Reading skills & 7 \\
\hline Logical thinking & 6 \\
\hline Format & 4 \\
\hline Grammar & 4 \\
\hline Planning & 4 \\
\hline Others (paraphrasing, revising, etc.) & 23 \\
\hline
\end{tabular}

The most commonly mentioned category was organization. There are two possible reasons for this. First, a considerable number of students learned the concept of how to organize an English essay for the first time and realized how different an English essay and a Japanese essay were. According to this survey, 45 percent of the participants had never learned how to write an English essay before entering the university (see Appendix $\mathrm{C}$ for the result of "About You" questions). Among the comments was "English essay organization is quite different from Japanese one and difficult to write. However, 1 [could] understand it through these practices." This comment illustrates the student's feeling of puzzlement and later satisfaction by learning the new style of writing an essay.

The other reason could be the fact that their teachers spent a great amount of time on teaching the organization of essays and paragraphs, which is crucial to the development of reading and writing skills. The course textbook emphasizes the organization of an essay and demonstrates it with concrete examples in all the chapters.

About the second open-ended question, 87 comments were written. These comments were also categorized into several groups and are displayed in Table 4.
Table 4. Things Students Reported They Wanted to Learn More

\begin{tabular}{lc}
\hline \multicolumn{1}{c}{ Category } & Number of comments \\
\hline Vocabulary & 25 \\
Rhetorical skills & 16 \\
Improving the speed & 9 \\
Organization & 6 \\
Preparation for the TOEFL & 5 \\
Paraphrasing & 5 \\
Grammar & 3 \\
Others (logical thinking, title, etc.) & 18 \\
\hline
\end{tabular}

The largest number of comments on vocabulary indicated students' strong desire to learn a wider variety of words. Many responses to this question include the adjectives academic and natural. Among those comments were "Vocabulary choice. Some vocabulary I wrote was unnatural to the native speaker. So she [the teacher] corrected," and "[l wanted to] read more academic stuff and learn more difficult vocabulary." The first comment suggests that the student wanted to learn more about vocabulary choice because his/her essay was corrected because some vocabulary used in the essay did not sound natural to the teacher, who was a native English speaker of English. The second comment straightforwardly expresses the student's desire to learn more academic vocabulary. Another student also explained the difficulty of word choice more articulately by saying "I want to know how to choose a word from some options that have similar meaning." These comments suggest that they have a strong desire to write their essays in an academically appropriate way; therefore, they feel the need of acquiring academic vocabulary they did not learn or use in high school English classroom.

The second largest category mentioned by the respondents was rhetorical skills. The respondents expressed their expectation to make their essays engaging for the reader. Expressions, such as more interesting and more powerful were often observed in their comments. Such a frequent use of comparative forms seems to suggest that they had some confidence in English writing, but they were not satisfied with their current writing skills. They wanted to further improve their writing skills. Among the comments were "[I wanted to learn] how to make my claim more powerful" and "[l wanted to learn] how to attract or convince readers in an essay." 
Some comments showed interests in specific rhetorical skills. For example, one student wrote, "[I wanted to learn] how to write an effective hook." Another student wrote, "[I wanted to learn] more advanced skills, for example using analogy or concession." These comments clearly show that the students were keenly aware of the reader of their essays and seem to set their expectations high in learning academic English writing.

\section{Analysis of Students' Desire for Improvement}

The two survey results conducted in 2018 and 2019 revealed the students' desire to develop their language skills, especially vocabulary. There are several possible reasons for their strong desire to learn vocabulary. One reason could be the result of their awareness of the difference between high school level English writing and academic essay writing at college. By receiving corrections from their teachers and revising their drafts, they would have recognized the need to learn academic words to write acceptable essays for their courses.

Another possible reason is the need for efficiency. In the second open-ended question about what they wanted to learn more in the course, the third largest category of their comments was improving the speed of reading and writing. It is understandable that the students think if they had more vocabulary, they could read and write faster. Leki and Swain (1994) pointed out the relation between students' desire to learn vocabulary and efficiency. They wrote that "their interest in language may be interest in efficiency and may reflect a desire in cut down workload and their work time" (p. 92). Their assumption could be applied to the respondents in this survey. The students were taking other courses in addition to required English classes, many of them had part-time jobs, and some were involved in extracurricular activities. For such students, efficiency must be an extremely valuable factor.

The third possible reason might be their concerns with the TOEFL. All the students in the program are required to take the TOEFL and the students are divided into different levels of English classes according to their TOEFL scores, which are also used as a criterion when they apply for the overseas program of the partner institutions. Vocabulary knowledge can be the base for all the sections of the TOEFL. Many books to tackle vocabulary for the TOEFL are sold at the university bookstore. It is natural for the students to expect to study more vocabulary in the classroom.

\section{Pedagogical Implications}

Some pedagogical implications could be drawn out from the results of this research. First, vocabulary education, especially academic vocabulary, should be emphasized more in the academic writing classroom. In the reading and writing textbook, vocabulary practices are usually conjunct with the content of the articles in the reading sections, but students might need to be familiar with words and phrases that are commonly used in academic essays and research papers. Extensive reading (or even listening) might play an important role to develop their vocabulary knowledge.

Next, grammar was the second most troubling factor for the students according to the survey, but the result of the second open-ended question did not indicate the students' strong desire to study grammar. Because the textbook has grammar exercises in all chapters, and the students had already studied grammar intensively in order to pass the university entrance examination, it can be surmised that many students were tired of studying grammar. In short, no matter how much they studied grammar, they still feel it is difficult.

Regarding grammar education in the classroom, there seems to be a gap between what they have learned and what they actually need. Common grammar exercises in the textbook and questions used in standardized English tests are usually multiple-choice or fill-in-the-blank type questions. In such questions, students choose one option from several choices and do not have to write a whole sentence with the target grammar rule. However, what the students need might be the practice of writing grammatically accurate sentences to express their own ideas. Moreover, proofreading activities should be regularly provided until students acquire the habit of checking their papers themselves before they submit them.

Third, paraphrasing should be taught systematically. Most writing textbooks do not provide detailed information about how to paraphrase although they often have summary questions. Just telling students to write the meaning of a passage in their own words without providing information on how to do it would overwhelm many students whose native languages are not English. If the textbook does not cover enough information, supplemental activities and materials to learn how to paraphrase should be provided by the teacher.

Teaching time in the classroom is limited; therefore, providing useful resources to promote self-study and clear guidance on how to study by themselves should be the key to developing students' English writing skills.

Limitations and Implication for Further Research

One of the limitations of this study was the scale of the survey, which was relatively small. Other limitations were that all the participants were 1st-year students and were 
liberal arts majors at a university. For these limitations, the results of this study may not be applicable to EFL writing courses in other contexts. Nevertheless, the results would provide EFL writing teachers with an insight into teaching academic writing in Japan. For further study, collecting more data at the university or other universities to examine students' troubling factors in English writing should bring a wider variety of information and deeper insights into teaching EFL writing. Besides, conducting further surveys among students with different majors, for example engineering, and comparing the differences between the two might be of great interest to researchers in the field of $\mathrm{L} 2$ teaching and college education.

\section{Conclusion}

This study of 141 first-year students at a university in Japan showed that the three most troubling factors in English writing were vocabulary, grammar, and paraphrasing. Thus, the students perceived that language-related factors were more difficult than structural/ idea-related factors.

The data of students' perceptions on writing difficulties should provide insights into how teachers can contribute to their students' development of English writing skills. Zamels (1987) said, "Writing skills can develop rapidly when students' concerns and interests are acknowledged" (as cited in Nunan, 1991, p. 88). It is hoped that this study would contribute to writing class instructors' better understanding of their students' perceptions of English academic writing.

\section{Bio Data}

Kyoko Okamoto has taught English for more than 20 years in the United States, Singapore, and Japan. She has obtained an MA in TESOL at California State University Hayward and taught developmental writing courses at the university. Currently she teaches academic reading and writing courses at Meiji University and Waseda University. Her research interests include academic reading, writing, and learning strategies. $<$ kokamoto@meiji.ac.jp>

\section{References}

Bitchener, J., \& Basturkmen, H. (2006). Perceptions of the difficulties of postgraduate L2 thesis students writing the discussion section. Journal of English for Academic Purposes, 5(1), 4-18. https://doi.org/10.1016/.j.eap.2005.10.002
Evans, S., \& Green, C. (2007). Why EAP is necessary: A survey of Hong Kong tertiary students. Journal of English for Academic Purposes, 6(1), 3-13. https://doi.org/10.1016/j.jeap.2006.11.005

Habibi, A., Wachyunni, S., \& Husni, N. (2017). Students' perception on writing problems: A survey at one Islamic university in Jambi, Ta'dib, 22(1), 96-108. Retrieved from https://www. researchgate.net/publication/322231831_Students'Perception_on_Writing_Problems_A_ Survey_at_One_Islamic_University_in_Jambi

Keong, Y. C., \& Mussa, I. H. (2015). Academic writing difficulties of Iraqi postgraduate students in Malaysia. International Education of Journal and Research, 3(6), 25-34

Lee, N. S., \& Tajino, A. (2008). Understanding students' perceptions of difficulty with academic writing for teacher development: A case study of the University of Tokyo writing program. Kyoto University Bulletin Paper, 14, 1-11. Retrieved from https://repository.kulib.kyoto-u.ac.jp/dspace/ bitstream/2433/70833/1/01_Nancy.pdf

Leki, I., \& Carson, J.G. (1994). Students' perceptions of EAP writing instruction and writing needs across the disciplines. TESOL Quarterly, 28(1), 81-101. https://doi.org/10.2307/3587199

Nunan, D. (1989). Designing tasks for the communicative classroom. Cambridge University Press, United Kingdom.

Nunan, D. (1991). Language teaching methodology: A text book for teachers. London: Prentice Hall International (UK) Ltd.

Appendix A

A Survey of Students' Perceptions on Their Writing Problems

1. Not at all difficult, 2. Not so difficult, 3. Neutral, 4. Somewhat difficult, 5. Very difficult

\begin{tabular}{lc}
\hline Finding a topic for an essay & $1 / 2 / 3 / 4 / 5$ \\
Brainstorming for an essay & $1 / 2 / 3 / 4 / 5$ \\
Start writing an essay & $1 / 2 / 3 / 4 / 5$ \\
Writing an outline & $1 / 2 / 3 / 4 / 5$ \\
Writing an introduction & $1 / 2 / 3 / 4 / 5$ \\
Writing a thesis statement & $1 / 2 / 3 / 4 / 5$ \\
Writing a topic sentence & $1 / 2 / 3 / 4 / 5$ \\
Writing supporting sentences & $1 / 2 / 3 / 4 / 5$ \\
Organizing a paragraph & $1 / 2 / 3 / 4 / 5$ \\
\hline
\end{tabular}


Okamoto: Three Most Troubling Factors in English Writing

\begin{tabular}{ll}
\hline Writing body paragraphs & $1 / 2 / 3 / 4 / 5$ \\
Writing a conclusion & $1 / 2 / 3 / 4 / 5$ \\
Organizing an essay & $1 / 2 / 3 / 4 / 5$ \\
Writing an English essay as a whole & $1 / 2 / 3 / 4 / 5$ \\
Paraphrasing & $1 / 2 / 3 / 4 / 5$ \\
Using quotations & $1 / 2 / 3 / 4 / 5$ \\
Writing a summary & $1 / 2 / 3 / 4 / 5$ \\
Writing a reaction statement & $1 / 2 / 3 / 4 / 5$ \\
Writing grammatically correct sentences & $1 / 2 / 3 / 4 / 5$ \\
Using appropriate vocabulary & $1 / 2 / 3 / 4 / 5$ \\
Avoiding plagiarism & $1 / 2 / 3 / 4 / 5$ \\
Others & $1 / 2 / 3 / 4 / 5$ \\
\hline
\end{tabular}

About You

Did you learn how to write an English essay before Yes / No entering university?

If yes, where did you learn?

What kind of things did you learn there?

Do you think learning how to write an English essay is 1 . Not at all important for you?

2. Little

3. Some extent

4. Rather much

5. Very much

Q1. What are the most important things you learned from Reading \& Writing Class? Q2. What are the things you wanted to learn more in Reading \& Writing Class?

\section{Appendix B}

Full Results of the Survey $(\mathrm{N}=141)$

\begin{tabular}{lcc|lcc}
\multicolumn{3}{c}{$2018(n=52)$} \\
\hline \multicolumn{1}{c}{ Item } & Mean & SD & \multicolumn{1}{c}{ Item } & Mean & SD \\
\hline Q1 Find Topic & 2.904 & 1.071 & Q1 Find Topic & 2.966 & 0.994 \\
Q2 Brainstorm & 2.712 & 0.832 & Q2 Brainstorm & 3.135 & 1.068 \\
Q3 Start Write & 2.904 & 1.053 & Q3 Start Write & 3.067 & 1.053 \\
Q4 Outlining & 2.942 & 1.037 & Q4 Outlining & 2.978 & 0.977 \\
Q5 Intro & 2.769 & 0.962 & Q5 Intro & 2.753 & 1.003 \\
Q6 Thesis & 2.692 & 0.805 & Q6 Thesis & 3.000 & 1.000 \\
Q7 Topic S & 2.569 & 0.878 & Q7 Topic S & 2.854 & 1.082 \\
Q8 Supp S & 3.058 & 0.802 & Q8 Supp S & 3.000 & 0.977 \\
Q9 Organize P & 3.059 & 0.904 & Q9 Organize P & 2.955 & 1.022 \\
Q10 Write Body & 3.135 & 0.793 & Q10 Write Body & 3.056 & 0.909 \\
Q11 Conclusion & 3.077 & 1.026 & Q11 Conclusion & 2.843 & 1.076 \\
Q12 Organize E & 3.212 & 0.977 & Q12 Organize E & 3.124 & 0.939 \\
Q13 Writ Whole & 3.154 & 0.849 & Q13 Writ Whole & 3.360 & 1.110 \\
Q14 Paraphrase & 3.519 & 1.075 & Q14 Paraphrase & 3.393 & 1.007 \\
Q15 Quotation & 3.231 & 0.854 & Q15 Quotation & 2.899 & 1.088 \\
Q16 Summary & 3.192 & 1.085 & Q16 Summary & 3.135 & 1.068 \\
Q17 Reaction & 3.077 & 0.926 & Q17 Reaction & 3.169 & 0.843 \\
Q18 Grammar & 3.421 & 0.957 & Q18 Grammar & 3.708 & 1.036 \\
Q19 Vocabulary & 3.385 & 0.932 & Q19 Vocabulary & 3.775 & 0.850 \\
Q20 Avoid Plag & 2.596 & 1.053 & Q20 Avoid Plag & 2.761 & 1.145 \\
\hline
\end{tabular}


Appendix C

"About You" Questions ( $N=141)$
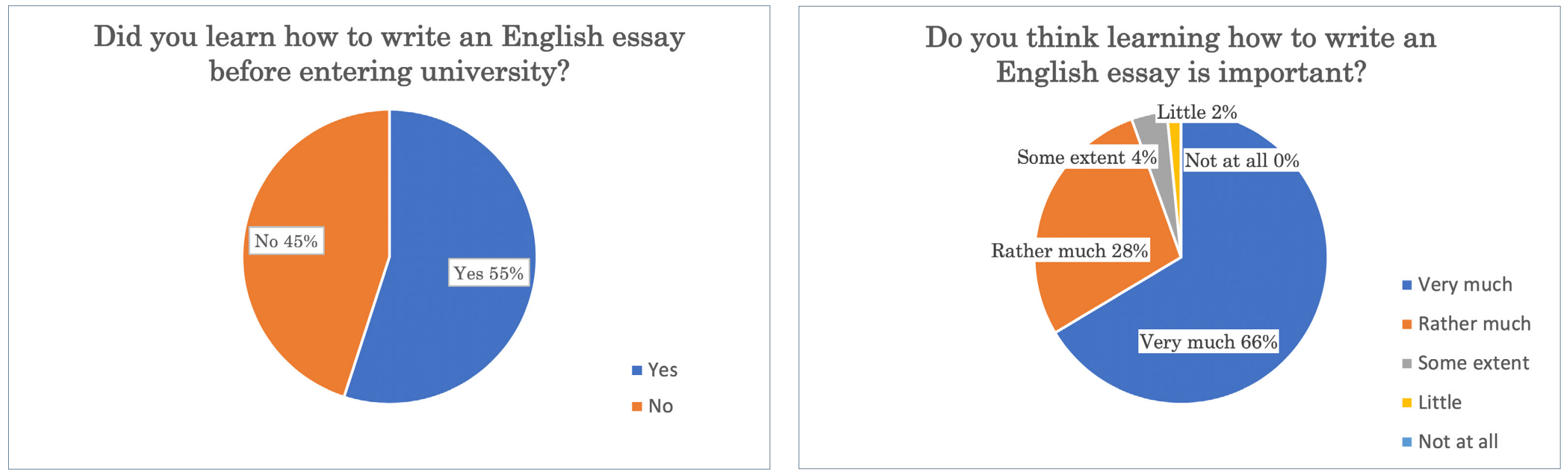